\title{
Knowledge and Attitude Towards Family Planning Among Women of Reproductive Age in Emerging Regions of Ethiopia
}

This article was published in the following Dove Press journal: Journal of Multidisciplinary Healthcare

\author{
Delayehu Bekele (D) \\ Feiruz Surur ${ }^{\prime}$ \\ Balkachew Nigatu' \\ Alula Teklu (iD) ${ }^{2}$ \\ Tewodros Getinet $\mathbb{D}^{3}$ \\ Munir Kassa (D) ${ }^{4}$ \\ Merhawi Gebremedhin (1D ${ }^{5}$ \\ Berhe Gebremichael (D) ${ }^{5}$ \\ Yonas Abesha ${ }^{6}$ \\ 'Department of Obstetrics and \\ Gynecology, Saint Paul's Hospital \\ Millennium Medical College, Addis Ababa, \\ Ethiopia; ${ }^{2}$ Saint Paul's Hospital Millennium \\ Medical College, Research Office, Addis \\ Ababa, Ethiopia; ${ }^{3}$ Public Health \\ Department, Saint Paul's Hospital \\ Millennium Medical College, Addis Ababa, \\ Ethiopia; ${ }^{4} \mathrm{Federal}$ Ministry of Health, \\ Ministry's Office, Addis Ababa, Ethiopia; \\ ${ }^{5}$ School of Public Health, Haramaya \\ University, Harar, Ethiopia; ${ }^{6}$ Private \\ Consultancy Practice, Addis Ababa, \\ Ethiopia
}

Background: Despite recent improvements in the use of contraceptives amongst married women in Ethiopia, the utilization rates are still far below the national figures in the emerging regions of the country. Therefore, there is a need to assess the level of knowledge and attitudes towards family planning, and associated factors among reproductive-age women in the four emerging regions of Ethiopia.

Methods: A community-based cross-sectional study was conducted among 2891 reproductive-age women from 01 to 30 June, 2017. The data were collected by open data equipped tablets with kit software using structured questionnaire. The collected data were exported to STATA version 14 for analysis. Knowledge and attitude were assessed using tools containing 12 and 9 questions, respectively. Mean scores were used as cut-off points. Internal consistency of the tool was checked using Cronbach alpha coefficient, and it was 0.87 for knowledge and 0.78 for attitude questions. Bivariate and multivariate analyses were done, and statistical significance was declared at $\mathrm{p}$-value $\leq 0.05$.

Results: Less than half, 1254 (43.4\%), of the participants had good knowledge and 1511 $(52.3 \%)$ had favorable attitude towards FP. Positive predictors of good knowledge of family planning were: being from Benishangul-Gumuz region, urban residence, older age, high level of education, being Christian and merchant, high household monthly income, and listening/ watching radio/TV. On the other hand, high family size and ideal desired children were negative predictors. For a favorable attitude, the positive predictors include older age, high level of partner education, listening/watching radio/TV, being from BG region and having a good knowledge of FP. Desiring high number of ideal children and being a student by occupation were negatively associated with a favorable attitude.

Conclusion: The study revealed that significant number of women had poor knowledge and attitude towards FP. Multiple socio-demographic factors contributed to knowledge and attitude of FP. Therefore, the health sectors of the regions and other stakeholders should strengthen the health extension program to disseminate messages related to FP to improve the knowledge and attitude of women.

Keywords: attitude, emerging regions, Ethiopia, family planning, knowledge, reproductiveage women

\section{Background}

Family planning (FP) helps couples and individuals realize their basic right to decide freely and responsibly if and when to have children, as well as how many children to have. The use of contraceptive methods results not only to improvements in health-related outcomes but also advance educational and economic
Correspondence: Merhawi Gebremedhin Email meriget12@gmail.com
Journal of Multidisciplinary Healthcare 2020:13 |463-|474

1463 
outcomes, especially for girls and women. ${ }^{1}$ More specifically, the use of contraceptives can save an estimated 2.7 million infant deaths and the loss of 60 million healthy lives globally each year. ${ }^{2}$ Similarly, contraceptive use can prevent at least $25 \%$ of all maternal deaths by preventing unintended pregnancies and unsafe abortions and also protect against sexually transmitted infections. ${ }^{3}$

The international community is committed to reducing the global maternal mortality ratio to less than 70 per 100,000 live births by 2030 as per the third Sustainable Development Goal. ${ }^{1,4,5}$ Pregnancy-related complications like abortion account for a large number of deaths amongst mothers and infants, particularly in developing nations. ${ }^{6}$

However, irrespective of its considerable benefits, FP practices are not being carried out by most of the developing countries. ${ }^{7}$ Worldwide in $2017,63 \%$ of married or in-union women were using some form of contraception, yet one in ten married or in-union women still have an unmet need for FP. ${ }^{1}$ The most rapid growth in the prevalence of contraceptive use in 2015 occurred in Asia (61\%) and Latin America (69\%). ${ }^{8}$

In Africa, as many as one in five women have an unmet need for FP and just $36 \%$ of married or in-union women were using contraception in 2017. ${ }^{1}$ The prevalence of contraceptive use in sub-Saharan Africa increased at a much slower pace reaching only $25 \%$ in $2015 .{ }^{8}$ Unmet need in 2017 was the highest (above 20\%, double the world average in 2017) in the regions of Eastern Africa, Middle Africa, Western Africa, and Melanesia, Micronesia and Polynesia, where contraceptive prevalence ranged from $20 \%$ in Western Africa to $43 \%$ in Eastern Africa. ${ }^{1}$

Evidence reveals several reasons for the lack of utilization of FP: lack of accessibility to contraceptive methods; minimal knowledge of contraceptive methods; fear of side effects; approbation based on social and religious sentiments; and provider bias. ${ }^{7,9}$ Most women of reproductiveage know very little or have incorrect information about FP methods. Even when they know some names of contraceptives, they do not know where to get them or how to use them properly. These women may also possess negative attitudes regarding FP, whereas some have heard false and misleading information. ${ }^{10,11}$

The Ethiopian Federal Ministry of Health (FMOH) has undertaken many initiatives to reduce maternal mortality. Among these initiatives, the most important is the provision of FP at all levels of the health care system. ${ }^{12,13}$ Currently, short-term modern FP methods are available at all levels of governmental and private health facilities, while a long-term method is being provided in health centers, hospitals and private clinics. ${ }^{13}$ However, the total fertility rate is 4.6 per woman, and the modern contraceptive prevalence rate for married women is strikingly low (35\%), especially in the emerging regions of the country such as Somali (1\%) and Afar (12\%) regions. ${ }^{14}$ Moreover, about one in every three births are unintended in Ethiopia as a consequence of unmet needs for family planning. ${ }^{15}$ These high levels of unintended pregnancies can pose serious health risks to mothers and their infants. ${ }^{16}$

Despite all the commitments of the Ethiopian FMOH to improving FP services, including information dissemination, the contraceptive prevalence rate in the emerging regions is far below the national average. This indicates as there are greater regional variations in FP utilization mainly in the emerging regions. Poor knowledge and unfavorable attitudes of FP methods could be among the reasons for the poor accomplishments of FP utilization in the emerging regions because most of the areas in the emerging regions are inaccessible with poor or no roads and few social services including schools and clinics. There are also very limited personnel in the specialist fields. Furthermore, literacy levels are very low particularly in the pastoral regions and not much different in the agro-pastoral regions as well. ${ }^{17}$

To our knowledge, there is a shortage of concrete information on the contraceptive knowledge and attitude among women in the emerging regions of Ethiopia. Therefore, this study was designed to assess the level of knowledge and attitudes of FP, and associated factors among reproductive-age women in the four emerging regions of Ethiopia.

\section{Methods and Materials Study Setting and Population}

A community-based cross-sectional study was conducted among women of reproductive-age (aged 15-49 years) from 01 to 30 June, 2017 in the four emerging regions of Ethiopia; namely Benishangul-Gumuz (BG), Gambela, Afar, and Somali regions. Benishangul-Gumuz (BG) and Gambela are agro-pastoral regions found in the western part of the country, whereas, Afar and Somali are pastoral regions and located in the eastern part. The total female population for Afar, BG, Gambela and Somali regions were $755,000,481,000,189,000$, and 2,420,000, respectively. Afar and Somali regions are with the lowest family planning uptake in the nation and tend to be in a declining 
trend. ${ }^{12,14,18-20}$ In contrast, BG and Gambela have relatively better contraceptive utilization that is close to the national average, but the urban-rural divide is unknown.

The study population includes all women of reproductive-age (aged 15-49 years) living in the emerging regions of Ethiopia. Women who were unable to communicate due to serious medical or mental health problems, immigrant and visiting women were excluded from the study to get appropriate and accurate data from the participants.

\section{Sample Size Estimation and Sampling Technique}

Considering the socio-cultural differences between the regions, the sample size was estimated independently for each emerging region. Since there was no similar literature showing the proportion of knowledge and attitude on FP in the same context, we used $\mathrm{p}=50 \%$ that provides the maximum sample size. Single population proportion formula was used by considering confidence level $=95 \%$, margin of error $=1 \%$, design effect $=2$ and $10 \%$ for anticipated nonresponders. Mathematically, $n_{h}=\left(z^{2}\right)(p)(1-p)(d)(r) /(c)$

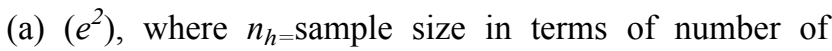
households to be selected, $z=$ level of confidence, $\mathrm{p}=$ proportion, $d=$ design effect, $r=$ multiplier to account for the anticipated rate of non-response, $c=$ proportion of total population contributed by the target population of the survey, $a=$ average household size, and $e^{2}=$ margin of error. Based on the formula, the final sample size was fixed at a total of 2929 women (i.e., 683, 805, 678 and 753 women for Afar, BG, Somali and Gambela regions, respectively).

Regarding the sampling procedure, all districts in each region were first listed. Accordingly, there were 30, 20, 53 and 13 districts in Afar, BG, Somali and Gambela regions, respectively. Then, from each region, $20 \%$ of all districts were randomly selected by lottery method (i.e., 6, 4, 10 and 3 districts for Afar, BG, Somali and Gambela regions, respectively). At the second stage, five kebeles (kebele is the smallest administrative unit in Ethiopia) from each selected district were randomly selected; and lastly, ten enumeration areas per district or two enumeration areas per selected kebele were included in the study. One enumeration area is expected to have an average of 80 households. A fresh household listing was recorded by the research team, and systematic random sampling was used to reach the actual participants. Sampling intervals of 7, 4, 12 and 3 were calculated for Afar, BG, Somali and
Gambela regions, respectively, by dividing the total household list to the expected sample per enumeration areas. Lottery method was used to select the first household from the interval for each region. In case a household has two or more eligible women, one of them was selected using lottery method for interview.

\section{Data Collection Tool and Procedure}

The study used a drafted questionnaire adapted from the Ethiopia Demographic and Health Survey (EDHS) 2016 ${ }^{14}$ and similar previous studies, ${ }^{3,21,22}$ and slightly modified to the context of the study. The questionnaire includes sociodemographic characteristics, reproductive history, knowledge, and attitude questions. After developing, the questionnaire was reviewed by the FMOH for any redundancy, vagueness, and illogical flow. Comments and suggestions from FMOH reviewers were incorporated and an advanced assessment tool was developed. After extensive revision, a final English version of the questionnaire was adopted and translated into the local languages (Amharic, Somali, and Afar languages) by respective language experts. The questionnaire was pretested in similar respondents living in non-study areas whose important feedbacks were incorporated.

Four days of training were given for field staff (data collectors and supervisors). They were health professionals, who had the skills of the local languages. The data collection was supervised, reported, and managed by the investigators. The data were collected by face-to-face interviews using a mobile installed with open data kit (ODK) application in an android tablet. The application allows saving and sending the completed questionnaire whenever data collectors get internet connections if data submission is not possible instantaneously (owing to poor connectivity). The data were submitted to a centralized data storage system as soon as the interview was completed. During the data collection period, closed households were visited three times and replaced randomly if not available.

\section{Operational Definitions}

Emerging region: the emerging regions in Ethiopia are least developed regions characterized by poor level of infrastructure and services; border and internal (clan) conflicts; strongly traditional in social practices; predominantly rural with small, scattered and nomadic population; dominated by pastoral and agro-pastoral as the basic means of livelihood; gender inequalities; poor 
capacity of regional and local government systems to deliver basic infrastructure and services. ${ }^{17}$

Knowledge of FP: to assess the knowledge of the participants, 12 questions related to the types of contraceptive methods were asked. Each question's response was coded as " 1 " for "yes" and "0" for "no". The internal consistency $(\alpha)$ of the items was checked and found to be 0.87 , which indicates an acceptable level of reliability. Then, the score was computed for each participant, which ranges from 0 to 12 . Finally, a composite knowledge variable was created from the score using the mean as a cut-off-point after the score was checked for normality. Participants with scores of mean and above were classified as having "good knowledge", and those with scores of below the mean were categorized as having "poor knowledge".

Attitude towards FP: the attitude of the participants towards modern contraceptive methods was assessed using 9 attitude related questions. Some of the questions were in the form of a Likert scale while others were not. Thus, all of the questions were recoded into binary form, and coded as " 1 " for "agree or yes" response and "0" for "disagree or no" response. The internal consistency $(\alpha)$ of the items was found to be 0.78 , indicating acceptable reliability. Then, attitude scores were computed for each participant, ranging from 0 to 9 . Finally, a composite attitude variable was created from the score using the mean as a cut-off-point upon checking normality of the scores. Participants with scores of mean and above were classified as having a "favorable attitude," whereas those with scores of below the mean were categorized as having an "unfavorable attitude."

\section{Data Processing and Analysis}

The data were coded and cleaned before analysis. The cleaned data were exported from the server to STATA version 14 for analysis. Descriptive statistics were described and presented using frequencies, summary measures, and tables.

Binary logistic regression analysis was done to see the association between each independent and dependent variables. Variables with $\mathrm{p}$-value $\leq 0.25$ from the bivariate analysis were included in the multivariate analysis model to control for the possible confounding factors after the collinearity of the variables was checked by using Variance Inflation Factor (VIF). Variables with VIF of $\geq 10$ were dropped from the final model. In addition, a goodness-of-fit model was checked by the Hosmer-
Lemeshow test. An insignificant $p$-value of this test indicates well-fitted model. Odds ratios with $95 \%$ confidence interval (CI) were reported to show the direction and strength of the association. The level of significance was considered at $\mathrm{p}$-value $\leq 0.05$.

\section{Results \\ Socio-Demographic and Reproductive History of Participants}

In total, 2891 participants were interviewed with a response rate of 98.7\%. Region-wise, 643 (22.2\%), 794 $(27.5 \%), 752(26 \%)$, and $702(24.3 \%)$ of the respondents were from Afar, BG, Gambela, and Somali regions, respectively. The mean age of participants was 26.8 ( \pm 7.5 SD) years. Nearly three-fourth (73.8\%) of the participants were rural residents. More than half, 1525 (52.7\%), had no formal education, and regarding partner education, 1150 (50.5\%) had no formal education; 2211 (76.5\%) participants were married/cohabited. More than half, 1713 (59.3\%), of participants were Muslim. The mean family size was 6 persons $( \pm 2.9$ SD); $41.8 \%$ with a family size of $3-6$, and $36.8 \%$ with $\geq 7$. Concerning occupation, $2038(70.5 \%)$ of them were engaged in labor works. More than half $(58.5 \%)$ of respondents had at least one communication media (radio or TV or cell phone) in their homes (Table 1).

The majority of the women $(85.6 \%)$ had experienced sexual intercourse with a mean age of 17.1 ( $\pm 3.1 \mathrm{SD})$ years at the time of first sexual intercourse. More than three-quarter of participants $(76.5 \%)$ had a history of pregnancy with 296 (13.4\%) ever undergoing an abortion and $120(5.43 \%)$ experiencing a stillbirth. For 1672 $(75.6 \%)$ of the respondents, their last pregnancy was wanted. The average number of pregnancies and live children were $4.2( \pm 2.8 \mathrm{SD})$ and $3.22( \pm 2.42 \mathrm{SD})$, respectively. In addition, $2003(69.3 \%)$ of the women reported wanting to have additional children. The average ideal number of children was reported at 7.07 ( $\pm 4.14 \mathrm{SD})$.

\section{Knowledge and Attitude of Women on Family Planning}

The study showed that 2394 (82.8\%) of the participants had knowledge of at least one contraceptive method. Only one-third (33\%) knew six or more (half of the list) contraceptive types. Overall, the mean knowledge score of FP was 4.3 ( $\pm 3.4 \mathrm{SD})$, and 1254 (43.4\%, 95\% CI: 41.6\%, $45.2 \%$ ) of the respondents had good FP knowledge. Good 
Table I Socio-Demographic Characteristics by Region (in Percentage) Among Reproductive-Age Women in the Four Emerging Regions of Ethiopia, 2017

\begin{tabular}{|c|c|c|c|c|c|}
\hline \multirow[t]{2}{*}{ Background Characteristics } & \multicolumn{5}{|l|}{ Region } \\
\hline & Afar (\%) & BG (\%) & Gambela (\%) & Somali (\%) & Total (\%) \\
\hline \multicolumn{6}{|l|}{ Education $(n=2891)$} \\
\hline No education & 78.38 & 38.41 & 29.12 & 70.80 & 52.75 \\
\hline Primary & 16.64 & 40.05 & 37.10 & 13.53 & 27.64 \\
\hline Secondary & 2.64 & II.71 & 23.67 & 10.26 & 12.45 \\
\hline Above Secondary & 2.33 & 9.82 & 10.11 & 5.41 & 7.16 \\
\hline \multicolumn{6}{|l|}{ Husband education $(n=2276)$} \\
\hline No education & 75.82 & 32.55 & 28.86 & 71.09 & 50.5 \\
\hline Primary & 14.10 & 37.42 & 19.19 & 7.13 & 20.4 \\
\hline Secondary & 4.95 & 15.25 & 21.22 & 11.29 & 13.44 \\
\hline Above Secondary & 5.13 & 14.78 & 30.73 & 10.50 & 15.64 \\
\hline \multicolumn{6}{|l|}{ Religion $(n=2891)$} \\
\hline Muslim & 96.73 & 48.74 & 3.46 & 96.58 & 59.25 \\
\hline Christian & 3.27 & 51.26 & 96.54 & 3.42 & 40.75 \\
\hline \multicolumn{6}{|l|}{ Employment status $(n=2891)$} \\
\hline Labor work/farmer & 89.42 & 75.94 & 58.24 & 75.07 & 74.13 \\
\hline Merchant & 3.42 & 6.30 & 4.65 & 9.69 & 6.05 \\
\hline Employee & 3.27 & 6.05 & 9.84 & 4.84 & 6.12 \\
\hline Student & 3.89 & II.7I & 27.26 & 10.40 & 13.70 \\
\hline \multicolumn{6}{|l|}{ Family monthly income $(n=289 \mid)$} \\
\hline$\leq$ Median(I000 ETB) & 100.00 & 44.46 & 51.20 & 32.38 & 55.64 \\
\hline > Median(I000 ETB) & 0.00 & 55.54 & 48.80 & 67.62 & 44.36 \\
\hline Have Radio (n=289I) & 32.19 & 30.35 & 8.51 & 16.24 & 21.65 \\
\hline Have Television $(n=2891)$ & $|4.3|$ & 18.39 & 14.89 & 27.64 & 18.82 \\
\hline Have personal cell phone $(n=289 \mid)$ & 41.84 & 45.72 & 47.21 & 54.99 & 47.49 \\
\hline \multicolumn{6}{|l|}{ Desired ideal children $(n=2891)$} \\
\hline I-4 children & 16.64 & 49.50 & 23.80 & 5.13 & 24.73 \\
\hline$\geq 5$ children & 83.36 & 50.50 & 76.20 & 94.87 & 75.27 \\
\hline
\end{tabular}

Abbreviations: BG, Benishangul-Gumuz; ETB, Ethiopian Birr.

knowledge was significantly higher among women from BG region $(62.7 \%, \mathrm{p}<0.001)$ followed by Gambela (41.1\%, $\mathrm{p}<0.001)$. The most commonly known contraceptive methods amongst participants were injectables (72.3\%), followed by pills (67.6\%) and implants (51.7\%). Health Extension Workers (HEWs) were the major source of family planning for $45.2 \%$ of the respondents, with health-care providers $(28.8 \%)$ and friends (24.7\%) following as sources for the participants (Table 2).

The mean score for overall attitude of FP was $4.0( \pm 2.5$ $\mathrm{SD})$, and more than half $(52.3 \%, 95 \%$ CI: $50.5 \%, 54.1 \%)$ of the respondents had a favorable attitude (above mean score) towards FP. The mean attitude score of FP also differed by location of residence where $4.5( \pm 2.4 \mathrm{SD})$ for urban residents and $3.8( \pm 2.5 \mathrm{SD})$ among rural dwellers. Meanwhile, there was a high regional variation in attitude mean score of FP with the lowest score in Somali $(2.4 \pm 1.8 \mathrm{SD})$ and highest score in BG $(5.8 \pm 2$ SD) (Table 3).

\section{Factors Associated with Knowledge and Attitude of FP}

Women in the age group of 25-34 years were 1.5 times [AOR (Adjusted Odds Ratio) $=1.5,95 \%$ CI $(1.2,1.8)]$ more likely to have good knowledge than those aged 15-24 years. In addition, the odds of good knowledge was 1.4 times higher among Christian women $[\mathrm{AOR}=1.4,95 \% \mathrm{CI}(1.1,2.0)]$. Concerning educational status, women who were educated to the secondary level and above were 3.6 times $[\mathrm{AOR}=3.6,95 \% \mathrm{CI}(1.6,7.9)]$ 
Table 2 Knowledge of Contraceptive Methods (in Frequency and Percentage) Among Reproductive-Age Women in the Four Emerging Regions of Ethiopia, 2017

\begin{tabular}{|c|c|c|c|c|c|c|}
\hline \multirow{2}{*}{\multicolumn{2}{|c|}{ Variables }} & \multicolumn{5}{|l|}{ Region } \\
\hline & & $\begin{array}{l}\text { Afar } \\
(n=643)\end{array}$ & $\begin{array}{l}\text { BG } \\
(n=794)\end{array}$ & $\begin{array}{l}\text { Gambela } \\
(n=752)\end{array}$ & $\begin{array}{l}\text { Somali } \\
(n=702)\end{array}$ & $\begin{array}{l}\text { Total } \\
(n=289 I)\end{array}$ \\
\hline \multicolumn{2}{|c|}{ Know at least one contraceptive method } & $581(90.4)$ & $76 \mid(95.8)$ & $538(71.5)$ & $514(73.2)$ & $2394(82.8)$ \\
\hline \multicolumn{2}{|l|}{ Know male condom } & $313(48.7)$ & $475(59.8)$ & $397(52.8)$ & $200(28.5)$ & $1385(47.9)$ \\
\hline \multicolumn{2}{|l|}{ Know pill } & $462(71.9)$ & $664(83.6)$ & $428(56.9)$ & $400(57.0)$ & $1954(67.6)$ \\
\hline \multicolumn{2}{|l|}{ Know injectable } & $506(78.7)$ & $730(91.9)$ & $446(59.3)$ & $407(58.0)$ & $2089(72.3)$ \\
\hline \multicolumn{2}{|l|}{ Know IUD } & $95(14.8)$ & $47 I(59.3)$ & $153(20.3)$ & $96(13.7)$ & $815(28.2)$ \\
\hline \multicolumn{2}{|l|}{ Know implants } & $211(32.8)$ & $696(87.7)$ & $336(44.7)$ & $252(35.9)$ & $\mid 495(5 \mid .7)$ \\
\hline \multicolumn{2}{|l|}{ Know tubal ligation } & $73(11.4)$ & 204(25.7) & $132(17.6)$ & $47(6.7)$ & $456(15.8)$ \\
\hline \multicolumn{2}{|l|}{ Know vasectomy } & $56(8.7)$ & $97(12.2)$ & $115(15.3)$ & $38(5.4)$ & $306(10.6)$ \\
\hline \multicolumn{2}{|l|}{ Female condom } & $77(12.0)$ & $173(21.8)$ & $256(34.0)$ & $71(10.1)$ & $577(20.0)$ \\
\hline \multicolumn{2}{|l|}{ Know LAM } & $349(54.3)$ & $244(30.7)$ & $158(21.0)$ & $368(52.4)$ & $1119(38.7)$ \\
\hline \multicolumn{2}{|l|}{ Know rhythm } & $230(35.8)$ & $388(48.9)$ & 285(37.9) & $224(31.9)$ & I I 27(39.0) \\
\hline \multicolumn{2}{|l|}{ Know withdrawal } & $109(17.0)$ & $|7|(2 \mid .5)$ & $72(9.6)$ & $76(10.8)$ & $428(14.8)$ \\
\hline \multicolumn{2}{|c|}{ Know emergency contraceptive } & $|4|(2 \mid .9)$ & $187(23.6)$ & $181(24.1)$ & $122(17.4)$ & $63 I(21.8)$ \\
\hline \multicolumn{2}{|c|}{ Good overall knowledge (composite) } & $222(34.5)$ & $498(62.7)$ & $309(4 I .1)$ & $225(32.1)$ & $1254(43.4)$ \\
\hline \multirow{9}{*}{$\begin{array}{l}\text { Source of contraceptive } \\
\text { Information }\end{array}$} & Friends & $170(26)$ & $208(26.2)$ & $174(23.1)$ & $163(23.2)$ & $715(24.7)$ \\
\hline & School & $90(14)$ & $186(23.4)$ & $158(2 \mid)$ & $77(11)$ & $511(17.7)$ \\
\hline & Family & $73(11)$ & $95(12.0)$ & $44(5.9)$ & $47(6.7)$ & $259(9)$ \\
\hline & HEWs & $310(48.2)$ & $56 \mid(70.7)$ & $276(36.7)$ & $159(22.6)$ & $1306(45.2)$ \\
\hline & $\begin{array}{l}\text { Healthcare } \\
\text { providers }\end{array}$ & $220(34.2)$ & $300(37.8)$ & $124(16.5)$ & $190(27.1)$ & $834(28.8)$ \\
\hline & Radio & $107(16.6)$ & $93(11.7)$ & $4(0.5)$ & $25(3.6)$ & $229(7.9)$ \\
\hline & Television & $62(9.6)$ & $92(11.6)$ & $40(5.3)$ & 63(9) & $257(8.9)$ \\
\hline & Printed-materials & $8(1.2)$ & $3(0.4)$ & $0(0.0)$ & $I(0.1)$ & $12(0.4)$ \\
\hline & $\begin{array}{l}\text { Internet/Social } \\
\text { Media }\end{array}$ & $8(12)$ & $I(0 . I)$ & $4(0.5)$ & $20(2.8)$ & $33(1.1)$ \\
\hline
\end{tabular}

Abbreviations: BG, Benishangul-Gumuz; HEWs, health extension workers; IUD, intrauterine device; LAM, lactational amenorrhea method.

more knowledgeable than those who had no formal education. Likewise, women having partners educated to the primary level were 1.4 times $[\mathrm{AOR}=1.4,95 \% \mathrm{CI}(1.1$, 1.9)] more likely to have good knowledge compared to those with no formal education. Occupation was also a predictor-merchant women were 2.4 times more knowledgeable than women engaged in daily laborer $[\mathrm{AOR}=2.4$, 95\% CI $(1.3,4.3)]$.

Women from the $\mathrm{BG}$ region were 1.6 times $[\mathrm{AOR}=1.6$, 95\% CI $(1.1,2.3)]$ more likely to have good knowledge compared to women from the Somali region. Similarly, women who lived in urban areas were found 1.6 times $[\mathrm{AOR}=1.6,95 \% \mathrm{CI}(1.2,2.2)]$ more knowledgeable than their counterparts. Women from households with a monthly income of 1000 Ethiopian Birr (ETB) and above were 1.4 times more knowledgeable than those with less than 1000 ETB [AOR=1.4, 95\% CI $(1.1,1.8)]$. Regarding media exposure, women who listen to radio/ watch TV were 2.2 times $[\mathrm{AOR}=2.2,95 \% \mathrm{CI}(1.6,2.8)]$ higher to have good knowledge compared to their counterparts.

Size of family was a consistent predictor of knowledge of FP; women from a family size of 6-10 persons were $30 \%$ less likely to have good knowledge compared to those from a family size of less than five $[\mathrm{AOR}=0.7$, $95 \%$ CI $(0.5,0.9)]$. Similarly, women who wanted to have five and above children were found to be $40 \%$ [AOR $=0.6,95 \%$ CI $(0.5,0.8)]$ less likely to have good knowledge compared to those who wanted to have less than five children.

The results of the attitude assessment showed that women who were in the age group of 24-35 years had 1.9 times $[\mathrm{AOR}=1.9,95 \% \mathrm{CI}(1.4,2.6)]$ more favorable attitude than those in the age group of 15-24 years. Furthermore, women whose husbands were educated up to the secondary level and above were found to have 2.6 
Table 3 Attitude of Contraceptive Methods (in Frequency and Percentage) Among Reproductive-Age Women in the Four Emerging Regions of Ethiopia, 2017

\begin{tabular}{|c|c|c|c|c|c|}
\hline \multirow[t]{2}{*}{ Variables } & \multicolumn{5}{|l|}{ Region } \\
\hline & $\begin{array}{l}\text { Afar } \\
(n=643)\end{array}$ & $\begin{array}{l}\text { BG } \\
(n=794)\end{array}$ & $\begin{array}{l}\text { Gambela } \\
(n=752)\end{array}$ & $\begin{array}{l}\text { Somali } \\
(n=702)\end{array}$ & $\begin{array}{l}\text { Total } \\
(n=2891)\end{array}$ \\
\hline \multicolumn{6}{|l|}{ Discussion with one's partner on FP } \\
\hline Frequently & $29(6.1)$ & $177(28.0)$ & $115(24.1)$ & $35(7.1)$ & $356(17.1)$ \\
\hline Sometimes & $5 I(10.7)$ & $239(37.8)$ & $109(22.8)$ & $30(6.0)$ & $429(20.6)$ \\
\hline Rarely & $78(16.3)$ & $58(9.2)$ & $20(4.2)$ & $36(7.3)$ & $192(9.2)$ \\
\hline Never & $320(66.9)$ & $159(25.1)$ & $234(49.0)$ & $395(79.6)$ & $1108(53.1)$ \\
\hline \multicolumn{6}{|l|}{ Discussion with family/relative on FP } \\
\hline Frequently & $14(2.2)$ & $52(6.5)$ & $25(3.3)$ & $6(0.9)$ & $97(3.4)$ \\
\hline Sometimes & $53(8.2)$ & $220(27.7)$ & $108(14.4)$ & $29(4.1)$ & $410(14.2)$ \\
\hline Rarely & $68(10.6)$ & $116(14.6)$ & $64(8.5)$ & $70(10.0)$ & $318(11.0)$ \\
\hline Never & $508(79.0)$ & $406(51.1)$ & $555(73.8)$ & $597(85.0)$ & 2066(7I.5) \\
\hline \multicolumn{6}{|l|}{ Discussion with friends on FP } \\
\hline Frequently & $23(3.6)$ & $66(8.3)$ & $5 \mathrm{I}(6.8)$ & $14(2.0)$ & $154(5.3)$ \\
\hline Sometimes & $67(10.4)$ & $239(30.1)$ & $180(23.9)$ & $53(7.5)$ & $539(18.6)$ \\
\hline Rarely & $77(12)$ & $143(18.0)$ & $79(10.5)$ & $73(10.4)$ & $372(12.9)$ \\
\hline Never & $476(74.0)$ & $346(43.6)$ & $442(58.8)$ & $562(80.1)$ & $1826(63.2)$ \\
\hline \multicolumn{6}{|l|}{ Contraception has benefit for women } \\
\hline Yes & $264(4 I . I)$ & $691(87.0)$ & $452(60.1)$ & $323(46.0)$ & $1730(59.8)$ \\
\hline No & 194(30.2) & $45(5.7)$ & $95(12.6)$ & $110(15.70)$ & $444(15.4)$ \\
\hline Do not know & $185(28.8)$ & $58(7.3)$ & $205(273)$ & $269(38.3)$ & $717(24.8)$ \\
\hline \multicolumn{6}{|l|}{$\begin{array}{l}\text { Large family size affects economic condition } \\
\text { negatively }\end{array}$} \\
\hline Strongly agree & $54(8.4)$ & $257(32.4)$ & $163(21.7)$ & $37(5.3)$ & $511(17.7)$ \\
\hline Agree & $174(27.1)$ & $417(52.5)$ & $259(34.4)$ & $123(17.5)$ & $973(33.7)$ \\
\hline Neutral & $52(8.1)$ & $31(3.9)$ & $91(12.1)$ & $51(7.3)$ & $225(7.8)$ \\
\hline Disagree & $269(41.8)$ & $69(8.7)$ & I78(23.7) & $349(49.7)$ & $865(29.9)$ \\
\hline Strongly disagree & $94(14.6)$ & $20(2.5)$ & $61(8.1)$ & $142(20.2)$ & $317(11.0)$ \\
\hline \multicolumn{6}{|l|}{ Large family size earns respect by the husband } \\
\hline Strongly agree & $129(20.1)$ & $32(4.0)$ & $78(10.4)$ & $138(19.7)$ & $377(13.0)$ \\
\hline Agree & $226(35.1)$ & $237(29.8)$ & $144(19.1)$ & $324(46.2)$ & $931(32.2)$ \\
\hline Neutral & $69(10.7)$ & $77(9.7)$ & $99(13.2)$ & $79(11.3)$ & $324(11.2)$ \\
\hline Disagree & $182(28.3)$ & $419(52.8)$ & $325(43.2)$ & $119(17.0)$ & $1045(36.1)$ \\
\hline Strongly disagree & $37(5.8)$ & 29(3.7) & $106(14.1)$ & $42(6.0)$ & $2 \mid 4(7.4)$ \\
\hline \multicolumn{6}{|l|}{ Large family size earns the respect of the community } \\
\hline Strongly agree & $107(16.6)$ & $26(3.3)$ & $75(10.0)$ & $157(22.4)$ & $365(12.6)$ \\
\hline Agree & $212(33.0)$ & $252(31.7)$ & $164(21.8)$ & $327(46.6)$ & $955(33.0)$ \\
\hline Neutral & $92(14.3)$ & $87(11.0)$ & III(I4.8) & $8 I(I I .5)$ & $371(12.8)$ \\
\hline Disagree & $183(28.5)$ & $406(51.1)$ & $294(39.1)$ & $105(15.0)$ & $988(34.2)$ \\
\hline Strongly disagree & $49(7.6)$ & $23(2.9)$ & $108(\mid 4.4)$ & $32(4.6)$ & $212(7.3)$ \\
\hline \multicolumn{6}{|l|}{ Large family size earns respect by a religious leader } \\
\hline Strongly agree & $156(24.3)$ & $18(2.3)$ & $98(13.0)$ & $122(17.4)$ & $394(13.6)$ \\
\hline Agree & $169(26.3)$ & 253(31.9) & $163(21.7)$ & $297(42.3)$ & $882(30.5)$ \\
\hline Neutral & $120(18.7)$ & $17 \mid(21.5)$ & $101(13.4)$ & $122(17.4)$ & $514(17.8)$ \\
\hline Disagree & $152(23.6)$ & $329(41.4)$ & $248(33.0)$ & $135(19.2)$ & $864(29.9)$ \\
\hline Strongly disagree & $46(7.2)$ & $23(2.9)$ & $142(18.9)$ & $26(3.7)$ & $237(8.2)$ \\
\hline
\end{tabular}

(Continued) 
Table 3 (Continued).

\begin{tabular}{|c|c|c|c|c|c|}
\hline \multirow[t]{2}{*}{ Variables } & \multicolumn{5}{|l|}{ Region } \\
\hline & $\begin{array}{l}\text { Afar } \\
(n=643)\end{array}$ & $\begin{array}{l}\text { BG } \\
(n=794)\end{array}$ & $\begin{array}{l}\text { Gambela } \\
(n=752)\end{array}$ & $\begin{array}{l}\text { Somali } \\
(n=702)\end{array}$ & $\begin{array}{l}\text { Total } \\
(n=289 I)\end{array}$ \\
\hline \multicolumn{6}{|l|}{ Large family size affects maternal and child health } \\
\hline Strongly agree & $78(12.1)$ & $190(23.9)$ & $125(16.6)$ & $46(6.6)$ & $439(15.2)$ \\
\hline Agree & $168(26.1)$ & $455(57.3)$ & $263(35.0)$ & 266(37.9) & $1152(39.8)$ \\
\hline Neutral & $79(12.3)$ & $44(5.5)$ & $106(14.1)$ & $88(12.5)$ & $317(11.0)$ \\
\hline Disagree & $250(38.9)$ & $94(11.8)$ & $198(26.3)$ & $240(34.2)$ & $782(27.0)$ \\
\hline Strongly disagree & $68(10.6)$ & $\mathrm{II}(\mathrm{I} .4)$ & $60(8.0)$ & $62(8.8)$ & $20 I(7.0)$ \\
\hline \multicolumn{6}{|l|}{ Overall attitude (composite) } \\
\hline Favorable & $214(33.3)$ & $687(86.5)$ & $464(61.7)$ & I46(20.8) & $|5| \mid(52.3)$ \\
\hline Unfavorable & $429(66.7)$ & $107(13.5)$ & $288(38.3)$ & $556(79.2)$ & $1380(47.7)$ \\
\hline
\end{tabular}

Abbreviations: BG, Benishangul-Gumuz; FP, family planning.

times $[\mathrm{AOR}=2.6,95 \% \mathrm{CI}(1.5,4.3)]$ more favorable attitude than women whose husbands had no formal education. Occupation wise, student women were $60 \%$ less likely to have a favorable attitude compared to daily laborers $[\mathrm{AOR}=0.4,95 \% \mathrm{CI}(0.2,0.7)]$. Women from the $\mathrm{BG}$ region had 8.8 times $[\mathrm{AOR}=8.8,95 \% \mathrm{CI}(5.6,13.8)]$ more favorable attitude than those who were from the Somali region. On the other hand, women who had exposure to radio/TV were 1.6 times $[\mathrm{AOR}=1.6,95 \% \mathrm{CI}(1.2$, 2.3)] more likely to have a favorable attitude than those who had no exposure. In addition, women who want to have five and more children were found $40 \%$ [AOR $=0.6$, $95 \%$ CI $(0.4,0.8)]$ less likely to have favorable attitude of FP compared to those who want to have less than five children. Moreover, women with better knowledge of contraceptives had 4.3 times [AOR=4.3, 95\% CI $(3.3,5.7)$ ] more favorable attitudes than women with poor knowledge (Table 4).

\section{Discussion}

Increasing program coverage and access of FP will not be enough unless all eligible women have adequate awareness or favorable attitude, and correctly and consistently practicing as per their need. Increasing awareness/knowledge and favorable attitude for practicing FP activities at all levels of eligible women are strongly recommended. ${ }^{13}$

The present study revealed that participants with good knowledge and favorable attitudes of FP account for $43.4 \%$ (95\% CI: $41.6 \%, 45.2 \%)$ and $52.3 \%$ (95\% CI: $50.5 \%, 54.1 \%$ ) of the sample size, respectively. The multivariate logistic regression revealed that being from $B G$ region, urban residence, older age, higher levels of education including one's partner, being Christian and merchant, earning a higher household monthly income and listening/watching radio/TV were found positive predictors of good knowledge of FP. On the other hand, large family size and a higher desired number of children were negative predictors. The positive predictors for those with a favorable attitude of FP included older age, higher level of partner education, exposure to TV/radio, being from the BG region, and possessing quality knowledge about FP. Interestingly, being a student by occupation was negatively associated with a favorable attitude.

Overall, the mean knowledge score was $4.3( \pm 3.4 \mathrm{SD})$, and $43.4 \%$ of the respondents had good knowledge of contraceptive methods. This was similar to two previous studies conducted in Ethiopia ${ }^{23,24}$ and one study from Nepal. $^{22}$ However, the results from other studies in Ethiopia, Nigeria, and India revealed better knowledge of contraceptives compared to the present study. ${ }^{14,23,25-35}$ The variations observed can be explained by the differences in socio-economic status, cultural norms, study setting, and access to information and health-care services.

This study revealed that women in the age group of 25-34 years were 1.5 times more likely to have good knowledge compared to those aged 15-24 years. This is in agreement with a study done in India. ${ }^{35}$ Besides, the odds of good knowledge was 1.4 times higher among Christian than Muslim women.

Women with a secondary level of education and above were 3.6 times more knowledgeable than those who had no formal education. Similarly, women with partners educated to the primary level were 1.4 times more likely to have good knowledge compared to those with no formal 
Table 4 Factors Associated with Knowledge and Attitude of Contraceptive Methods Among Reproductive-Age Women in Emerging Regions of Ethiopia, 2017

\begin{tabular}{|c|c|c|c|c|c|}
\hline \multirow[t]{2}{*}{ Independent Variables } & \multirow[t]{2}{*}{ Categories } & \multicolumn{2}{|l|}{ Knowledge } & \multicolumn{2}{|l|}{ Attitude } \\
\hline & & COR $(95 \% \mathrm{CI})$ & AOR $(95 \% \mathrm{Cl})$ & COR $(95 \% \mathrm{CI})$ & AOR $(95 \% \mathrm{Cl})$ \\
\hline Region & $\begin{array}{l}\text { Afar } \\
\text { BG } \\
\text { Gambela } \\
\text { Somali }\end{array}$ & $\begin{array}{l}1.00 \\
3.1(2.5,3.9)^{* *} \\
1.3(I . I, I .6)^{*} \\
0.8(0.7 I, I . I)\end{array}$ & $\begin{array}{l}1.00 \\
1.6(I .1,2.3)^{*} \\
0.6(0.3,1.1) \\
0.8(0.5,1.2)\end{array}$ & $\begin{array}{l}1.00 \\
12.8(9.9,16.7)^{* *} \\
3.2(2.5,4.0)^{* *} \\
0.5(0.4,0.7)^{* *}\end{array}$ & $\begin{array}{l}1.00 \\
8.8(5.6,13.8)^{* *} \\
2.5(1.4,4.6)^{*} \\
0.4(0.3,0.6)^{* *}\end{array}$ \\
\hline Residence & $\begin{array}{l}\text { Rural } \\
\text { Urban }\end{array}$ & $\begin{array}{l}1.00 \\
2.6(2.2,3.1)^{* *}\end{array}$ & $\begin{array}{l}1.00 \\
\text { I.6(I.2,2.2)** }\end{array}$ & $\begin{array}{l}1.00 \\
1.4(1.2,1.7)^{* *}\end{array}$ & $\begin{array}{l}1.00 \\
0.7(0.5,1.1)\end{array}$ \\
\hline Age (in years) & $\begin{array}{l}15-24 \\
25-34 \\
35-49\end{array}$ & $\begin{array}{l}\mathrm{I} .00 \\
\mathrm{I} .5(\mathrm{I} .2, \mathrm{I} .8)^{* *} \\
\mathrm{I} .4(\mathrm{I} . \mathrm{I}, \mathrm{I} .7)^{*}\end{array}$ & $\begin{array}{l}1.00 \\
1.6(1.2,2.0)^{* *} \\
1.3(0.9,1.9)\end{array}$ & $\begin{array}{l}\text { I.00 } \\
\text { I.5(I.2,I.8)** } \\
\text { I.5(I.2,I.9)** }\end{array}$ & $\begin{array}{l}1.00 \\
1.9(1.4,2.6)^{* *} \\
2.1(1.4,3.1)^{*}\end{array}$ \\
\hline Family size & $\begin{array}{l}1-5 \\
6-10 \\
>11\end{array}$ & $\begin{array}{l}1.00 \\
0.47(0.40,0.54)^{* *} \\
0.33(0.23,0.47)^{* *}\end{array}$ & $\begin{array}{l}1.00 \\
0.7(0.5,0.9)^{*} \\
0.4(0.2,0.7)^{*}\end{array}$ & $\begin{array}{l}\text { I.00 } \\
0.5(0.4,0.6)^{* *} \\
0.3(0.2,0.4)^{* *}\end{array}$ & $\begin{array}{l}1.00 \\
0.9(0.7,1.2) \\
0.8(0.5,1.4)\end{array}$ \\
\hline Religion & $\begin{array}{l}\text { Muslim } \\
\text { Christian }\end{array}$ & $\begin{array}{l}1.00 \\
\text { I.8(I.5,2.I })^{* *}\end{array}$ & $\begin{array}{l}1.00 \\
1.4(1.1,2.0)^{*}\end{array}$ & $\begin{array}{l}1.00 \\
3.7(3.2,4.4)^{* *}\end{array}$ & $\begin{array}{l}1.00 \\
1.2(0.8,2.0)\end{array}$ \\
\hline Level of education & $\begin{array}{l}\text { No } \\
\text { Primary } \\
\text { Secondary } \\
\text { Above secondary }\end{array}$ & $\begin{array}{l}1.00 \\
3.1(2.6,3.7)^{* *} \\
6.1(4.7,7.9)^{* *} \\
19.3(12.6,29.6)^{* *}\end{array}$ & $\begin{array}{l}1.00 \\
\text { I.5(I.I,2.0)* } \\
3.4(2.1,5.7)^{* *} \\
3.6(I .6,7.9)^{*}\end{array}$ & $\begin{array}{l}1.00 \\
4.2(3.5,5.1)^{* *} \\
5(3.8,6.4)^{* *} \\
9.3(6.4,13.6)^{* *}\end{array}$ & $\begin{array}{l}1.00 \\
1.4(0.9,1.9) \\
1.4(0.8,2.6) \\
1.4(0.7,3.3)\end{array}$ \\
\hline Husband education & $\begin{array}{l}\text { No } \\
\text { Primary } \\
\text { Secondary } \\
\text { Above secondary }\end{array}$ & $\begin{array}{l}1.00 \\
3.2(2.5,4.0)^{* *} \\
3.9(3.0,5.1)^{* *} \\
6.8(5.3,8.9)^{* *}\end{array}$ & $\begin{array}{l}1.00 \\
1.4(1.1,1.9)^{*} \\
1.3(0.9,2.0) \\
1.5(0.9,2.3)\end{array}$ & $\begin{array}{l}1.00 \\
4.9(3.8,6.2)^{* *} \\
4.8(3.7,6.4)^{* *} \\
7.6(5.7,10.1)^{* *}\end{array}$ & $\begin{array}{l}1.00 \\
1.4(1,1.9) \\
2(1.2,3.2)^{*} \\
2.6(1.5,4.3)^{* *}\end{array}$ \\
\hline Occupation & $\begin{array}{l}\text { Laborer } \\
\text { Merchant } \\
\text { Employee } \\
\text { Student }\end{array}$ & $\begin{array}{l}1.00 \\
2.9(2.1,4.0)^{* *} \\
8.4(5.6,12.6)^{* *} \\
1.9(1.5,2.4)^{* *}\end{array}$ & $\begin{array}{l}1.00 \\
2.4(1.3,4.3)^{*} \\
1.2(0.6,2.2) \\
0.9(0.5,1.5)\end{array}$ & $\begin{array}{l}1.00 \\
\text { I.6(I.2,2.2)* } \\
4.2(2.8,6.0)^{* *} \\
\text { I.8(I.5,2.3)** }\end{array}$ & $\begin{array}{l}1.00 \\
1.9(0.9,3.8) \\
1.4(0.7,3.1) \\
0.4(0.2,0.7)^{*}\end{array}$ \\
\hline Household monthly income & $\begin{array}{l}<1000 \text { ETB } \\
\geq 1000 \text { ETB }\end{array}$ & $\begin{array}{l}1.00 \\
2.0(1.7,2.3)^{* *}\end{array}$ & $\begin{array}{l}1.00 \\
1.4(1.1,1.8)^{*}\end{array}$ & $\begin{array}{l}1.00 \\
1.6(1.4,1.8)^{* *}\end{array}$ & $\begin{array}{l}I .00 \\
I(0.7, I .4)\end{array}$ \\
\hline Listening/watching radio/TV & $\begin{array}{l}\text { No } \\
\text { Yes }\end{array}$ & $\begin{array}{l}1.00 \\
4(3.4,4.8)^{* *}\end{array}$ & $\begin{array}{l}1.00 \\
2.2(1.6,2.8)^{* *}\end{array}$ & $\begin{array}{l}1.00 \\
2.9(2.4,3.4)^{* *}\end{array}$ & $\begin{array}{l}1.00 \\
1.6(1.2,2.3)^{*}\end{array}$ \\
\hline Total live children & $\begin{array}{l}\leq 4 \\
>4\end{array}$ & $\begin{array}{l}1.00 \\
0.38(0.32,0.46)^{* *}\end{array}$ & $\begin{array}{l}1.00 \\
0.8(0.6,1.1)\end{array}$ & $\begin{array}{l}1.00 \\
0.4(0.3,0.5)^{* *}\end{array}$ & $\begin{array}{l}1.00 \\
0.8(0.6,1.2)\end{array}$ \\
\hline Ideal desired children & $\begin{array}{l}<5 \\
\geq 5\end{array}$ & $\begin{array}{l}1.00 \\
0.29(0.24,0.35)^{* *}\end{array}$ & $\begin{array}{l}1.00 \\
0.6(0.5,0.8)^{*}\end{array}$ & $\begin{array}{l}1.00 \\
0.18(0.15,0.23)^{* *}\end{array}$ & $\begin{array}{l}1.00 \\
0.6(0.4,0.8)^{*}\end{array}$ \\
\hline Knowledge & $\begin{array}{l}\text { Poor } \\
\text { Good }\end{array}$ & $\longrightarrow$ & $\longrightarrow$ & $\begin{array}{l}1.00 \\
6.8(5.8,8.1)^{* *}\end{array}$ & $\begin{array}{l}1.00 \\
4.3(3.3,5.7)^{* *}\end{array}$ \\
\hline
\end{tabular}

Notes: ${ }^{*}$ p-value $<0.05 ;{ }^{*}$ p-value $<0.001$.

Abbreviations: AOR, adjusted odds ratio; BG, Benishangul-Gumuz; $\mathrm{Cl}$, confidence interval; COR, crude odds ratio; ETB, Ethiopian Birr.

education. This is in line with other study reports. ${ }^{22,35,36}$ Women who listen to radio/watch TV were 2.2 times more likely to have good knowledge compared to those with no exposure to radio/TV. The possible explanation for these associations could be that women with a higher level of education and those exposed to media are more likely to have more information, understand the message easily, and might have received lessons on contraceptive methods in 
the curricula at school. The access to educational resources as well as media exposure is typically improved in urban areas, which can potentially explain why participants from the $\mathrm{BG}$ region were 1.6 times more knowledgeable than women from the Somali region. In the Somali region, which is more rural, information access to FP is limited. This trend is consistent with a study report from India. ${ }^{25}$

Women who desired five or more children were $40 \%$ less likely to have good knowledge than those with four and below. Likewise, women with a family size of 6 or more were $30 \%$ less likely to have good knowledge of FP than those with less than six. This indicates that women with large families are less exposed to FP education. Such women may also be more religious, non-educated, and living in rural areas. Similarly, those who are merchants by occupation and earn a high monthly income were 2.4 and 1.4 times more likely to have good knowledge compared to those who are farmers/laborers and less monthly income, respectively. This is similar with other different studies. ${ }^{22,35,36}$ Some possible reasons are that being a merchant allows for mobility, which as a result, may provide more information from different sources. Similarly, merchants mostly live in urban areas which are easy for information access from the television or radio as well as from healthcare providers.

The mean attitude score was $4.0( \pm 2.5 \mathrm{SD})$, and $52.3 \%$ of the respondents had a favorable attitude towards FP. This was consistent with studies done in Eastern Ethiopia ${ }^{23}$ and India. ${ }^{35,37}$ However, this is lower compared to other different studies done in Ethiopia, ${ }^{14,24,25}$ India $^{38}$ and Nepal. ${ }^{22}$ This might be due to differences in study scale (sample size), socio-cultural practices, and access to information on FP.

Women from BG and Gambela were at higher odds ( $\mathrm{AOR}=8.8$ and 2.5, respectively) to have a favorable attitude than women from Somali region. Similarly, older women (age 25-49) had more favorable attitudes than women from the lowest age sector of 15-24 years. This finding is consistent with studies done in the Jimma zone of Ethiopia ${ }^{27}$ and Nepal. ${ }^{22}$ This can be explained as age increases, information through experience may increase thereby influencing attitude. Additionally, as women get older they may become less eager to bear more children.

Interestingly, while educational level positively predicted one's knowledge of FP, it did not seem to influence a women's attitude. However, the education level of their husbands/partners significantly influenced their reported attitude towards FP. As the level of the partner's education increased, the participant's attitude towards FP improved. Women with a partner of primary education were 1.4 times more likely to have favorable attitude compared to those having no formal education. In addition, women with partner education of secondary level and above were 2 and 2.6 times, respectively, at higher odds of having favorable attitude than partners with no education. This finding was consistent with a study conducted in Turkey. ${ }^{39}$ Moreover, women who had listening radio/TV were 1.6 times more likely to have a favorable attitude than those who were not exposed.

Women with ideal desire children of $\geq 5$ were at lower odds (0.6) to have favorable attitude than their counterparts. Participants with good knowledge of contraceptive were 4.3 times more likely to have favorable attitude than women with poor knowledge that was in line with a study conducted in Turkey. ${ }^{39}$

Occupation wise, student women were $60 \%$ less likely to have favorable attitude compared to daily laborers. Similarly, women who want to have five and above children were found $40 \%$ less likely to have a favorable attitude compared to those who want to have less than five children. This is straight forward that women who want to have many children will not have favorable attitude on FP.

\section{Conclusions}

The overall score of knowledge and attitude was found to be low. Different socio-demographic and reproductive health characteristics were significantly associated with good knowledge and favorable attitude of FP. Stakeholders concerned on family planning should work together to bring behavioral change on FP in the emerging regions of Ethiopia through providing information, education and communication. Community/religious/clan leaders should be integral parts in all of the efforts.

\section{Abbreviations}

AOR, Adjusted Odds Ratio; BG, Benishangul-Gumuz; CI, Confidence Interval; COR, Crude Odds Ratio; EDHS, Ethiopia Demographic and Health Survey; ETB, Ethiopian Birr; FMOH, Federal Ministry of Health; FP, Family Planning; ODK, Open Data Kit; SD, Standard Deviation; VIF, Variance Inflation Factor.

\section{Data Sharing Statement}

Data are available from corresponding author upon reasonable requesting. 


\section{Ethical Clearance}

This study was conducted in accordance with the Declaration of Helsinki. Ethical clearance was secured from Institutional Review Board (IRB) of the Saint Paul's Hospital Millennium Medical College (SPHHMC) on 09 July, 2016 with a reference number P.M/23/29/2016. Before the initiation of the data collection, informed voluntary written and signed consent was obtained from each participant. For participants aged less than 18 years, the informed voluntary written and signed consent was obtained from their parents/guardians. The interviews were carried out privately in separate rooms/places. All possible identifiers were excluded from the data collection tools to ensure participants' confidentiality.

\section{Acknowledgment}

Authors would like to extend gratitude to $\mathrm{FMoH}$ for providing budget and technical support. Heads of regional health bureau of the four emerging regions, supervisors and data collectors are acknowledged for their unreserved effort. Also, we are thankful to Mrs. Elly Cowan for language edition. Lastly but not least we acknowledge all participants.

\section{Author Contributions}

All authors made a significant contribution to the work reported, whether that is in the conception, study design, execution, acquisition of data, analysis and interpretation, or in all these areas; took part in drafting, revising or critically reviewing the article; gave final approval of the version to be published; have agreed on the journal to which the article has been submitted; and agree to be accountable for all aspects of the work.

\section{Funding}

Ethiopian FMoH funded this study. The funder has no role in designing the study, data collection, analysis, interpretation and writing up of the manuscript.

\section{Disclosure}

The authors report no conflicts of interest for this work.

\section{References}

1. United Nations. World family planning 2017-highlights (ST/ESA/SER. A/414); 2017. Available from: https://www.un.org/en/development/desa/ population/publications/pdf/family/WFP2017_Highlights.pdf.

2. Darroch JE, Singh S, Nadeau J. In Brief (No.5) New York. Contraception: An Investment in Lives, Health and Development. New York: Guttmacher Institute and UNFPA; 2008.
3. Weldegerima B, Denekew A. Women's knowledge, preferences, and practices of modern contraceptive methods in Woreta, Ethiopia. Res Social Adm Pharm. 2008;4:302-7. doi:10.1016/j.sapharm.2007.10.001

4. United Nations General Assembly. Transforming our world: the 2030 agenda for sustainable development. General assembly resolution 70/ 1; 2015. Available from: http://www.un.org/ga/search/view_doc.asp? symbol=A/RES/70/1\&Lang=E.

5. WHO. Trends in Maternal Mortality 1990 to 2015 Estimates by WHO, UNICEF, UNFPA. Geneva: World Bank Group and the United Nations Population Division; 2015.

6. Donovan P, Wulf D. Family planning can reduce high infant mortality levels. Alan Guttmacher Inst. 2002;(2):1-4.

7. WHO. Fact sheet on family planning/contraception; 2018. Available from: http://www.who.int/mediacentre/factsheets/fs351/en/.

8. United Nations Department of Economic and Social Affairs Population Division. Estimates and Projections of Family Planning Indicators. New York: United Nations; 2018.

9. Jahan U, Verma K, Gupta S, et al. Awareness, attitude and practice of family planning methods in a tertiary care hospital, Uttar Pradesh, India. Int J Reprod Contracept Obstet Gynecol. 2017;6:500-6. doi:10.18203/2320-1770.ijrog20170370

10. Olugbenga-Bello AI, Abodunrin OL, Adeomi AA. Contraceptive practices among women in rural communities in South-Western Nigeria. Glob J Med Res. 2011;11.

11. Oyedokun AO. Determinants of contraceptive Usage: lessons from women in Osun State, Nigeria. J Human Soc Sci. 2007;1:1-14.

12. Central Statistical Agency. Ethiopia mini demographic and health survey 2014. Addis Ababa. 2014. Available from: http://www.dktethiopia. org/publications/ethiopia-mini-demographic-and-health-survey-2014.

13. Federal Ministry of Health. National guideline for family planning services in Ethiopia; 2011. Available from: http://www.moh.gov.et/ documents/20181/21665/National+Family+Planning+Guideline_ Ethiopia_2011.pdf/.

14. Central Statistical Agency (CSA) [Ethiopia] and ICF. Ethiopia Demographic and Health Survey 2016. Addis Ababa, Ethiopia, and Rockville, Maryland, USA: CSA and ICF; 2016.

15. Singh S, Darroch JE, Vlassoff M, Nadeau J. Adding It Up. The Benefits of Investing in Sexual and Reproductive Health Care 2014. New York: Guttmacher Institute and UNFPA; 2014.

16. Lule E, Singh S, Chowdhury SA. Fertility Regulation Behaviors and Their Costs: Contraception and Unintended Pregnancies in Africa, Eastern Europe \& Central Asia. Washington, DC: World Bank; 2007.

17. Government of Ethiopia Ministry of Federal Affairs. Emerging Regions Development Program (ERDP). 2011.

18. Central Statistical Agency (CSA). Ethiopia Demographic and Health Survey 2000. Addis Ababa, Ethiopia. 2000.

19. Central Statistical Agency (CSA). Ethiopia Demographic and Health Survey 2005. Addis Ababa, Ethiopia. 2005.

20. Central Statistical Agency (CSA). Ethiopia Demographic and Health Survey 2011. Addis Ababa, Ethiopia. 2011.

21. Alege SG, Matovu JKB, Ssensalire S, Nabiwemba E. Knowledge, sources and use of family planning methods among women aged 15-49 years in Uganda: a cross-sectional study. Pan Afri Med J. 2016;24:39. doi:10.11604/pamj.2016.24.39.5836

22. Thapa P, Pokharel N, Shrestha M. Knowledge, attitude and practices of contraception among the married women of reproductive age group in selected wards of Dharan Sub-Metropolitan City. J Contracept Stud. 2018;(3):18. doi:10.21767/2471-9749.100051

23. Kasa AS, Tarekegn M, Embiale M. Knowledge, attitude and practice towards family planning among reproductive age women in a resource limited settings of Northwest Ethiopia. BMC Res Notes. 2018;11:577. doi:10.1186/s13104-018-3689-7

24. Kedir GJ, Legesse TW, Seid Y. Contraceptive utilization among couples and associated factors in Dodota District, Oromia Region, Ethiopia. Biomed J Sci Tech Res. 2018;4(1). doi:10.26717/BJSTR. 2018.04.000986 
25. Sharma V, Mohan U, Das V, Awasthi S. Socio-demographic determinants and knowledge, attitude, practice: survey of family planning. J Fam Med Prim Care. 2012;1(1):43-47. doi:10.4103/2249-4863.94451

26. Aynekulu WT, Buruh G. Measuring fertility intention, family planning utilization and associated factors among married couples in Mekelle City, Tigray, Ethiopia; Cross-sectional Study. IJPBSF. 2013;6(1).

27. Tilahun T, Coene G, Luchters S, et al. Family planning knowledge, attitude and practice among married couples in Jimma Zone, Ethiopia. PLoS One. 2013;8(4):e61335. doi:10.1371/journal.pone. 0061335

28. Gupta V, Mohapatra D, Kumar V. Family planning knowledge, attitude, and practices among the currently married women (aged 15-45 years) in an urban area of Rohtak district, Haryana. Int J Med Sci Public Health. 2016;5:627-632. doi:10.5455/ijmsph.2016.12082015100

29. Nigussie AT, Girma D, Tura G. Postpartum family planning utilization and associated factors among women who gave birth in the past 12 months, Kebribeyah Town, Somali Region, Eastern Ethiopia. J Women's Health Care. 2016;5:340. doi:10.4172/2167-0420.1000340

30. Samuel A, Uliso A, Olle B, Dambe D, Nigatu M, Sorato MM. Assessment of modern contraceptive method utilization and associated factors among women of reproductive age group at Arba Minch Town, SNNPR, Ethiopia. EC Gynaecol. 2017;6(2):36-53.

31. Gizaw W, Zewdu F, Abuhay M. Extended postpartum modern contraceptive utilization and associated factors among women in Gozamen District, East Gojam Zone, Northwest Ethiopia. Insights Reprod Med. 2017;1(2).

32. Lamaro T, Tadele N. Family planning service utilization and its associated factors among married women in Benchi-Maji Zone, Southwest, Ethiopia: community-based cross-sectional study. Clin Mother Child Health. 2017;14:258. doi:10.4172/2090-7214.1000258
33. Ekpenyong MS, Nzute AI, Odejimi O, Abdullahi AD. Factors influencing utilization of family planning services among females of reproductive age (15-45 years) in the Bauchi local government area, Bauchi state of Nigeria. Nurs Palliat Care. 2018;3(2):2-6. doi:10.15761/NPC.1000180

34. Abraha TH, Belay HS, Welay GM. Intentions on contraception use and its associated factors among postpartum women in Aksum town, Tigray region, northern Ethiopia: a community-based cross- sectional study. BMC Reprod Health. 2018;15:188. doi:10.1186/s12978-0180632-2

35. Sindhu BM, Angadi MM. Knowledge, attitude and practice about family planning methods among reproductive age group women in a Tertiary Care Institute. Int J Sci Stud. 2016;4(2):133-136.

36. Sherpa SZ, Sheilini M, Nayak A. Knowledge, attitude, practice and preferences of contraceptive methods in Udupi district, Karnataka. J Family Reprod Health. 2013;7:115-120.

37. Pegu B, Gaur BP, Sharma N, Singh AS. Knowledge, attitude and practices of contraception among married women. Int $J$ Reprod Contracept Obstet Gynecol. 2014;3:385-388. doi:10.5455/23201770.ijrcog20140620

38. Qazi M, Saqib N, Gupta S. Knowledge, attitude and practice of family planning among women of reproductive age group attending outpatient department in a tertiary centre of Northern India. Int $J$ Reprod Contracept Obstet Gynecol. 2019;8(5):1-9. doi:10.18203/2320-1770.ijrcog20191531

39. Ayaz S, Efe SY. Family planning attitudes of women and affecting factors. J Turk Ger Gynecol Assoc. 2009;10:137-141.
Journal of Multidisciplinary Healthcare

\section{Publish your work in this journal}

The Journal of Multidisciplinary Healthcare is an international, peerreviewed open-access journal that aims to represent and publish research in healthcare areas delivered by practitioners of different disciplines. This includes studies and reviews conducted by multidisciplinary teams as well as research which evaluates the results or conduct of such teams or healthcare processes in general. The journal

\section{Dovepress}

covers a very wide range of areas and welcomes submissions from practitioners at all levels, from all over the world. The manuscript management system is completely online and includes a very quick and fair peer-review system. Visit http://www.dovepress.com/testimonials. php to read real quotes from published authors. 